\title{
Pengaruh Latihan Fisik terhadap Penyakit Diabetes Melitus Tipe II: Fokus pada Telomer
}

\section{Thressia Hendrawan $^{1 *}$, Swandito Wicaksono ${ }^{2}$}

${ }^{1}$ Departemen Fisiologi, Fakultas Kedokteran, Universitas Pelita Harapan, Tangerang, Indonesia

${ }^{2}$ Departemen Fisiologi, Fakultas Kedokteran dan Ilmu Kesehatan, Universitas Bengkulu, Bengkulu, Indonesia

*Corresponding Author. E-mail: thressia.h@ gmail.com, Mobile number: +62 878-8102-1939

\begin{abstract}
ABSTRAK
Telomer merupakan bagian penting dalam penyimpanan informasi dalam kromosom kita. Setiap pembelahan sel, telomer akan mengalami pemendekkan dan akan memberikan suatu signal bahaya pada saat mencapai batas tertentu. Selain dari pemendekkan sel, ada berbagai macam hal yang bisa menyebabkan pemendekan telomer. Gaya hidup sedenter, kebiasaan merokok, indeks masa tubuh yang tinggi, dan penyakit-penyakit kronis lain sering memberikan efek pada panjang telomer. Banyak penelitian yang menyatakan Latihan fisik dapat berpotensi untuk menahan proses pemendekkan telomer. Ada berbagai mekanisme molekuler yang terkait dengan permasalahan maupun solusi yang ada dalam latihan fisik tersebut. Pencegahan penyakit metabolik telah banyak dikaitkan dengan latihan fisik. Penuaan sel yang dapat ditahan oleh aktivitas fisik maupun latihan fisik dapat menjadi salah satu jalur yang dapat dipikirkan mengenai mekanisme molekuler tersebut
\end{abstract}

Kata kunci: Latihan fisik; diabetes melitus; telomer

\section{ABSTRACT \\ Telomeres are an important part of storing information on our chromosomes. Every cell division, telomere will experience shortening and will give a danger signal when it reaches a certain limit. Apart from cell shortening, there are various kinds of things that can cause telomere shortening. Sedentary lifestyle, smoking habits, high body mass index, and other chronic diseases often affect telomere length. \\ (Berlanjut dihalaman selanjutnya)}

Article history:

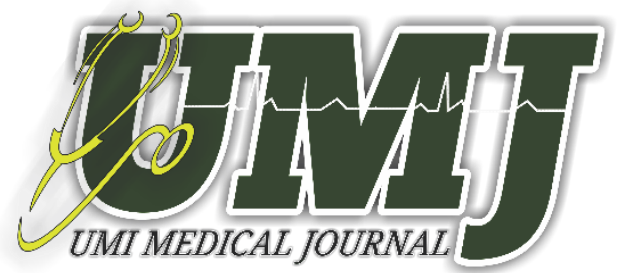

Received: 15 Oktober 2020

Accepted: 23 Juni 2020

Published: 28 Desember2020

Published by :

Fakultas Kedokteran

Universitas Muslim Indonesia

Phone:

+6282293330002
Address:

Jl. Urip Sumoharjo Km. 5 (Kampus II UMI)

Makassar, Sulawesi Selatan.

Email:

medicaljournal@umi.ac.id 


\section{(Lanjutan halaman sebelumnya)}

However, many studies suggest that physical exercise can have the potential to withstand the telomere shortening process. There are various molecular mechanisms related to the problems and solutions that exist in physical exercise. Prevention of metabolic diseases has been widely associated with physical exercise. Cell aging that can be held back by physical activity and physical exercise can be one of the pathways that can be thought one of the molecular mechanisms.

Keyword: Physical exercise; diabetes mellitus; telomere

\section{PENDAHULUAN}

Definisi dari diabetes melitus menurut American Diabetes Association (ADA) 2010 adalah merupakan suatu kelompok penyakit metabolik dengan karakteristik hiperglikemia yang terjadi karena kelainan sekresi insulin, kerja insulin, atau kedua-duanya. World Health Organization (WHO) memprediksi kenaikan jumlah penyandang DM di Indonesia dari 8,4 juta jiwa pada tahun 2000 menjadi sekitar 21,3 juta pada tahun 2030. International Diabetes Federation (IDF) pada tahun 2009, memprediksi jumlah pasien DM dari 7 juta pada tahun 2009 menjadi 12 juta pada tahun 2030. Berdasarkan laporan diatas menunjukkan adanya peningkatan jumlah pasien dengan DM sebesar 2-3 kali lipat pada tahun 2030.

\section{Pemendekan Telomere dan Konsekuensinya}

Telomer adalah sebuah struktur yang berulang dan ditemukan pada ujung kromosom. Sampai saat ini diketahui fungsi dari telomer adalah untuk melindungi kromosom dari degradasi, rekombinasi, dan fusi interkromosom. Telomer memiliki peran penting dalam menyimpan informasi dalam kromosom kita. Dalam kondisi normal, telomer akan berkurang sedikit demi sedikit setiap kali sel mengalami pembelahan. Setelah mencapai batas tertentu, sel akan mengalami penurunan fungsi dan bahkan mengalami apoptosis. Panjang dari telomer diperkirakan dapat digunakan untuk menentukan rentang hidup sebuah sel dan organisme tersebut. ${ }^{1}$

Penelitian yang dilakukan oleh Goglin et al. (2016) menunjukkan adanya pengaruh pemendekan telomer terhadap mortalitas pasien dengan jantung koroner. Dalam rentang waktu 5 tahun, mortalitas dialami oleh $39 \%$ pasien dengan pemendekan telomer, $22 \%$ pasien dengan panjang telomer yang tetap, dan $12 \%$ pasien dengan pemanjangan telomer. Dapat kita lihat bahwa peningkatan panjang telomer dalam rentang waktu 5 tahun dapat menurunkan mortalitas pada pasien jantung koroner. ${ }^{2}$

Pemendekan telomer terjadi seiring dengan pertambahan usia. Hal ini terjadi di semua jaringan kecuali otak dan myocardium. ${ }^{3}$ Salah satu teori penyebab terjadinya penuaan adalah akibat spesies oksigen reaktif 
(ROS) yang menyebabkan stres oksidatif (OS). ${ }^{4}$ Rata-rata pengurangan panjang telomer setiap tahunnya adalah 20-60 bp. ${ }^{3}$ Tingkat pengurangan panjang telomer ini dapat meningkat maupun berkurang bergantung pada faktor gaya hidup yang spesifik. ${ }^{1}$ Selain itu, pada beberapa penyakit yang diderita seseorang, dapat diamati adanya peningkatan pemendekan telomer seperti pada diabetes tipe 2. Telomer akan bertambah pendek selama durasi diabetes. Bertambah pendek telomer ini diduga karena terjadinya peningkatan progresif pada inflamasi dan/atau stres oksidatif yang memiliki peran dalam pemendekan telomer. ${ }^{5}$

Gaya hidup sedenter, disertai dengan kebiasaan merokok, indeks massa tubuh (BMI) yang tinggi, dan status sosio-ekonomi yang rendah memberikan efek pada telomer leukosit (LTL). Hal ini berpotensi mempercepat terjadinya penuaan. Penelitian yang dilakukan oleh Cherkas et.al. (2007) menemukan bahwa panjang LTL subjek paling aktif diantara 2401 sukarelawan, memiliki 200 nukelotida lebih panjang dibandingkan dengan subjek yang paling tidak aktif. ${ }^{6}$

Latihan fisik yang kita lakukan memproduksi radikal bebas berlebih yang dapat menyebabkan terjadinya stres oksidatif. ${ }^{4,7}$ Tubuh memiliki sistem antioksidan alami yang dapat membantu mengurangi OS. Sistem ini dapat dikembangkan dengan berolahraga. ${ }^{7}$

Beberapa penelitian telah menyebutkan bahwa latihan fisik dapat mempertahankan panjang telomer. ${ }^{8-}$

${ }^{10} \mathrm{Hal}$ ini terkait dengan telomer yang sampai saat ini dianggap suatu biomarker untuk umur biologis. ${ }^{8}$ Disebutkan juga latihan fisik dapat memberikan manfaat pada beberapa penyakit ini melalui mekanisme penjagaan integritas panjang telomer.

Mekanisme molekuler yang terkait dengan pemanjangan telomer ini juga masih belum diketahui secara jelas. Pasien dengan T2DM, mempunyai telomer yang lebih pendek dibandingkan normal. Pemendekan telomer diketahui berhubungan dengan adanya keadaan resistensi insulin. Pemendekan ini juga semakin diperparah dengan adanya komplikasi-komplikasi penyakit diabetes, seperti retinopati, nefropati, dan penyakit kardiovaskular. ${ }^{11}$

Berdasarkan uraian di atas, masih dibutuhkan banyak penelitian mengenai telomer dan faktor-faktor yang memengaruhinya, agar dapat menerangkan berbagai hal yang terkait dengan pemendekan telomer dalam memengaruhi kesehatan seseorang. Demikian juga perlu dipelajari berbagai upaya pencegahan berbagai penyakit melalui latihan fisik. Dalam makalah ini penulis berusaha untuk menghubungkan manfaat dari latihan fisik terhadap telomer dihubungkan dengan kondisi diabetes melitus, yang selanjutnya Latihan fisik diharapkan dapat menjadi metode untuk pencegahan penyakit diabetes melitus.

\section{Telomer}

Telomer merupakan suatu nukleoprotein yang khusus, berada dalam ujung kromosom. Telomer ini mempunyai peran penting dalam menunjang struktur dan fungsi kromosom. Telomer dari mamalia 
bervariasi antara 5-15 ribu pasang basa $(\mathrm{kb})$ dan bisa memendek 20-50 pasang basa setiap tahunnya. Telomer dapat memendek karena ketidakmampuan dari enzim replikasi DNA untuk menyalin keseluruhan ujung 3 dari leading strand.

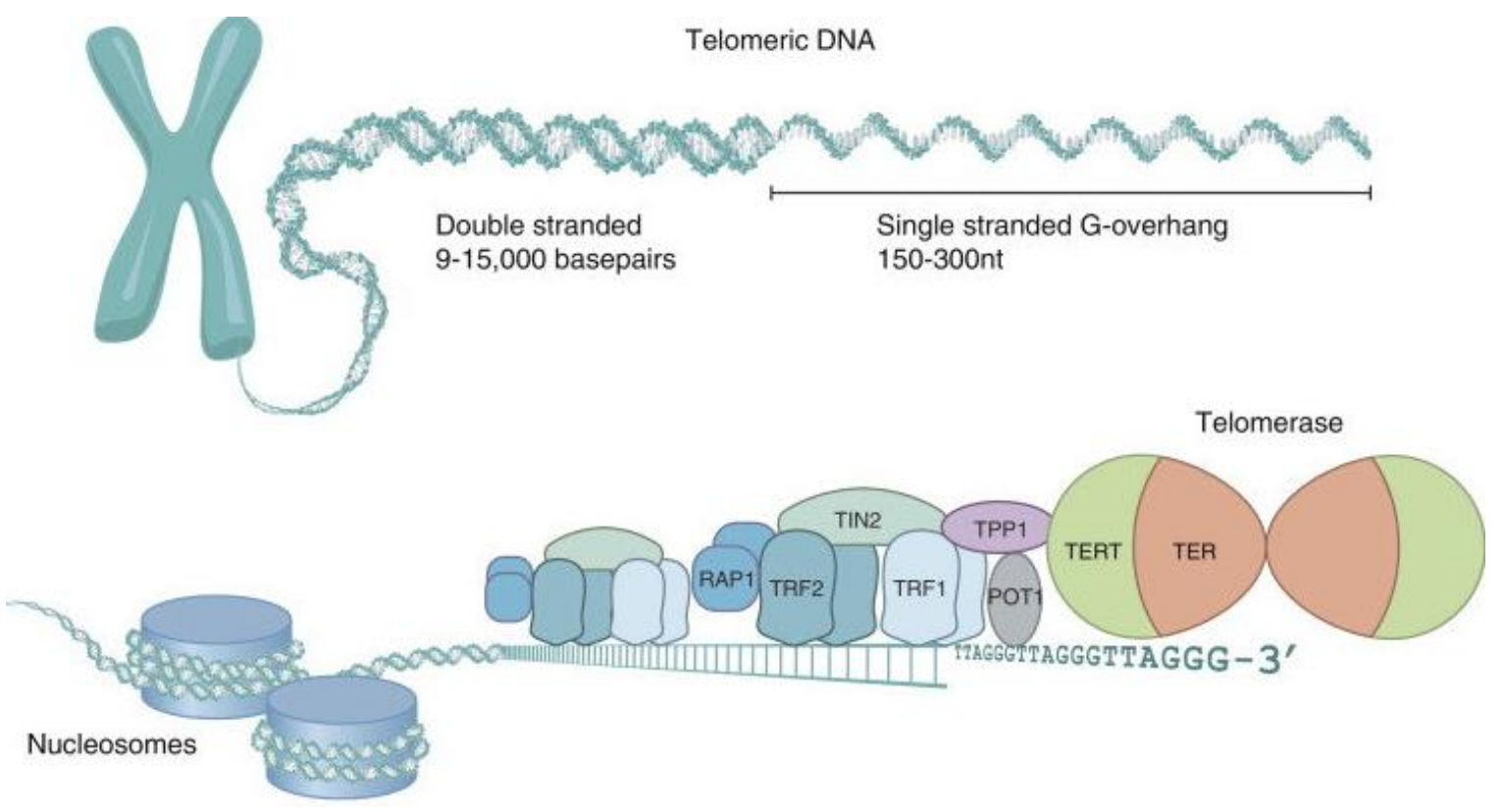

Gambar 1.1. DNA telomer ${ }^{31}$

Telomer yang memendek selama replikasi sel, saat telomer sudah sangat pendek, maka akan mencetuskan signal bahwa sel telah menua melalui berbagai jalur apoptosis maupun penuaan sel. Beberapa diantaranya melalui jalur Mutasi Ataxia telangiektasia (ATM), Ataxia telangiektasia yang terkait dengan RAD (ATR), P21, P53.

Hal ini kemudian menurunkan kapasitas dari sel dan secara keseluruhan akan menurunkan vitalitas dari keseluruhan jaringan yang ada. Keberadaan telomer sendiri ditunjang oleh 6 protein yang secara kolektif disebut dengan protein shelterin. Shelterin ini mendukung keberadaan telomer dengan menurunkan signal yang akan merusak DNA dan juga membantu mengatur panjang telomer. Protein-protein yang berkaitan dengan telomer tersebut adalah Telomer repeat binding faktor 1 (TRF 1), Telomer repeat binding faktor 2 (TRF 2), TRF-interacting nuclear faktor (TNIF-1), Adenocortical dysplasia homolog (TPP1), Protection of telomeres 1 (POT1), TRF2-interacting protein (TRF2IP).

Protein-protein ini akan berikatan dengan telomer dan meregulasi panjangnya. Telomer dan shelterin ini membentuk struktur yang khusus yaitu $t$ dan $d$ loops. Mereka berfungsi sebagai kepala pelindung pada kromosom. Kepala ini kemudian akan mencegah fusi dari ujung-ujung kromosom tersebut dan membuat replikasi DNA dapat berlangsung dari ujung terminal 3' ke ujung terminal 5' secara lengkap. 
Masing-masing komponen protein shelterin ini memiliki berbagai fungsi. TRF1 dan TRF2 ditemukan banyak pada telomer. TRF1 untuk mengatur panjang telomer secara negatif dan TRF2 berfungsi untuk melindungi fusi dari ujung-ujung telomer antar kromosom dan juga penuaan sel.

TINF2 meregulasi dengan cara berinteraksi dengan TRF1 dan TRF2. TPP1 dan POT1 berikatan dengan DNA single stranded (untai G yang overhang) dan berinteraksi untuk merekrut dan meningkatkan proses telomerase dalam memperpanjang telomer.

TRF2 dan POT1 bekerja secara terpisah untuk melindung DNA dari jalur-jalur respon signal kerusakan DNA. TRF2 bekerja pada jalur ATM dan POT1 bekerja pada jalur ATR. Hal ini juga sekaligus akan melindungi panjang dari telomer.

TRF2IP atau biasa dikenal dengan RAP1 berikatan pada telomer dengan berinteraksi dengan TRF2 dan berkontribusi juga dalam mencegah peristiwa fusi.

Pada intinya fungsi dari Shelterin adalah untuk melindungi stabilitas dari panjang telomer, mencegah kerusakan kromosom, dan juga menekan aktivasi jalur perusakan DNA pada bagian telomernya dengan membentuk $t$ dan $d$ loops.

Hal-hal lain dapat membuat telomer memendek lebih cepat, misalnya inflamasi pada dan stress oksidatif. Stres oksidatif (SO) dapat mempercepat pemendekan telomer, karena bagian telomer triplet GGG DNA itu lebih rentan terhadap ROS. Pada penelitian von Zglinicki T pada tahun 2002 menyebutkan bahwa antioksidan dapat menghambat pemendekan telomer pada percobaan invitro. Belum terlalu jelas mengenai mekanisme bagaimana inflamasi yang berlebihan dapat memicu pemendekan telomer. Diperkirakan adanya inflamasi berlebih memicu pembelahan sel, sehingga dengan itu membuat pemendekan telomer menjadi lebih cepat. ${ }^{8}$

Selain dari adanya efek langsung ROS terhadap telomer, mekanisme perbaikan terhadap lesi oksidatif ini juga kurang efisien dibandingkan dengan lesi pada bagian DNA yang lain. Ditemukan bahwa paparan stres oksidatif yang berulang meningkatkan frekuensi dari pemecahan single-strand dan dapat diperbaiki dalam 1 hari pada bagian DNA selain telomer, sedangkan pada bagian telomer lebih lambat dan tidak bisa secara lengkap. Lalu pada inflamasi, biasa terdapat factor-faktor proinflamasi seperti TNF $\alpha$, dan ditemukan bahwa TNF $\alpha$ mempunyai hubungan berbanding terbalik dengan aktivitas telomerase. ${ }^{12}$

Sekurang-kurangnya ada dua mekanisme dimana ROS menyebabkan pemendekan telomer. Pertama, DNA telomer yang sangat rentan terhadap stress oksidatif pada urutan GGG. Kedua, peningkatan stress oksidatif ini juga dapat menyebabkan TERT inti keluar menuju sitoplasma dan membuat aktivitas TERT inti berkurang. 19 
Dengan demikian, dapat dikatakan bahwa peningkatan ROS pada penderita DM akan mengakibatkan fungsi telomerase sebagai pengatur panjang telomer dengan mensintesis untai DNA telomerik tidak berjalan secara maksimal.

Ada gen yang dinamakan ataxia telangiectasia mutated gene (ATM) yang mengkode protein kinase yang akan diaktivasi untuk berespon pada pemecahan single-strand dan dipikirkan merupakan hal yang penting utuk memelihara integritas dan stabilitas kromosom. Telah disebutkan juga bahwa orang dengan kelainan ataksia telangiektasia telah terpapar secara kronis terhadap stress oksidatif dan mempunyai kemampuan yang kurang untuk merawat atau memperbaiki telomer DNA. ${ }^{12}$

Untuk mengukur panjang telomer ini dapat dipergunakan berbagai metode. Saat ini cara pengukuran panjang telomer yang sederhana namun dapat tepat guna adalah dengan menggunakan PCR kuantitatif (qPCR). Metode ini adalah perkembangan dari metode dari Cawthon 2002 untuk mengukur panjang telomer. ${ }^{16}$

\section{Penyakit diabetes mellitus tipe 2 dan telomer}

Pada bagian ini akan dibahas mengenai panjang telomer dalam konteks penyakit metabolik yaitu diabetes melitus tipe 2 (T2DM). Diabetes melitus tipe 2 adalah kelainan multifaktorial yang menjadi penyebab utama dari morbiditas, mortalitas dan beban sosial-ekonomi dalam dunia. ${ }^{17}$ Penyakit ini mempunyai ciri hiperglikemia yang dikarenakan adanya gangguan pada reseptor insulin maupun sekresi insulin.

Patofisiologi dari diabetes mellitus menunjukkan aspek terkait dengan usia. Pertama, prevalensi T2DM meningkat dengan usia. Kedua terdapat banyak kejadian mengganggu kesehatan yang terkait dengan usia tua, seperti aterosklerosis dan disfungsi kognitif, yang juga dieksaserbasi dan sering muncul pada pasien T2DM. Oleh karena itu penting untuk dapat diklarifikasi mekanisme dari T2DM yang dapat mempercepat disfungsi dari berbagai jenis organ. Salah satunya adalah berhubungan dengan telomer. ${ }^{18}$

Penyakit T2DM ini, seperti penyakit metabolik lainnya berkaitan dengan stres oksidatif yang meningkat. Telah diketahui pula bahwa stres oksidatif ini memainkan peran kunci dalam pemendekan telomer pada pasien DM. Karena penyakit kronis yang terkait dengan usia, seperti penyakit kardiovaskular dan T2DM mempunyai telomer yang lebih pendek dan seluruhnya mempunyai karakteristik inflamasi dan stress oksidatif . ${ }^{8}$

Diabetes, sering terkait dengan obesitas yang berasal dari asupan yang tinggi akan karbohidrat dan lemak. Kondisi obesitas ini bisa menyebabkan status proinflamatorik dengan stress oksidatif. Lebih jauh lagi peningkatan TNF $\alpha$ dan IL-6 telah dilaporkan mengganggu aksi insulin dengan menekan signal transduksi tersebut. Interupsi seperti ini bisa menekan sifat antiinflamasi dari insulin dan konsekuensi yang 
dapat terjadi adalah pemendekkan telomer. Dari penelitian Dandona P et.al. (2001), memperlihatkan dengan infus insulin menurunkan pembentukan ROS dan menekan ekspresi oksidatif dari NADPH dan pengikatan $\mathrm{NF} k B .{ }^{12}$

Salah satu hipotesis yang menyatakan bahwa telomer yang lebih pendek akan membuat fenotip yang lebih menua pada beberapa sel, dan termasuk di dalamnya adalah sel beta. Sehingga peristiwa selanjutnya adalah terjadinya apoptosis pada sel beta itu yang akan memunculkan penyakit diabetes. Telomer-telomer yang lebih pendek ini ditemukan dan bahkan lebih pendek pada kelahiran individu-individu yang memiliki predisposisi diabetes. Peristiwa kehilangan telomernya meningkat karena adanya kehilangan telomer saat pembelahan sel yang disebabkan karena peningkatan stres oksidatif pada keadaan prediabetes. ${ }^{21}$

Penelitian lain yang mendukung hal ini, didapatkan telomer lebih pendek pada sel progenitor epitel sirkulasi pada pasien dengan sindrom metabolik dan pada kondisi lain dengan stres oksidatif, seperti merokok dan obesitas. Pasien dengan resistensi insulin yang tinggi atau penderita DM tipe 2 mempunyai kecenderungan untuk mengalami pola aterosklerosis yang difus dan ekstensif. Penderita diabetes seringkali memperlihatkan komplikasi vaskular yang mencolok, termasuk memiliki penyakit infark miokardium dan stroke. Olivieri F et al. (2011), menyatakan bahwa pasien T2DM dengan komplikasi diabetes mempunyai telomer yang lebih pendek secara progresif dibandingkan dengan pasien T2DM yang tidak mempunyai komplikasi. ${ }^{11}$

ROS ini akan menyebabkan terjadinya stres oksidatif. Pada keadaan kadar gula yang tinggi, level dari antioksidan intraselular akan menurun, contohnya glutation (GSH) dan tioredoksin. Tidak seimbangnya ROS dengan antioksidan yang ada, akan menyebabkan banyak gangguan pada signaling intraseluler. ${ }^{23}$ Salah satunya adalah terhadap DNA genom dan telomer. ${ }^{24}$

\section{Latihan fisik dan telomer}

Latihan fisik yang teratur tidak hanya terkait dengan menurunnya faktor risiko penyakit metabolik, tetapi juga menurunkan gejala penyakit tersebut. Seringkali disamakan antara istilah aktivitas fisik dan latihan fisik. Aktivitas fisik dan latihan fisik merupakan istilah yang memiliki makna yang berbeda. Aktivitas fisik adalah semua bentuk gerakan tubuh yang dihasilkan dari kontraksi otot skeletal,sedangkan latihan fisik adalah bentuk dari aktivitas fisik yang teratur, terencana dan terstruktur dan bertujuan untuk meningkatkan atau memertahankan satu atau lebih komponen kebugaran fisik. ${ }^{25}$

Perbedaan fisiologis yang paling utama dari latihan fisik jenis aerobik dan anaerobik adalah penggunaan proses metabolism aerob dalam menghasilkan energi tanpa adanya akumulasi asam laktat di dalam darah. Contoh latihan fisik jenis aerobik seperti jogging.

Latihan fisik jenis anaerobik ditandai dengan adanya upaya fisik intensitas tinggi sampai maksimal yang dilakukan dalam periode waktu yang singkat. Energi diperoleh melalui metabolisme anaerob, sehingga 
akan menyebabkan akumulasi asam laktat di dalam darah. Contoh latihan fisik tipe anaerobik seperti lari cepat (sprint).

Latihan fisik yang bersifat akut ditandai dengan latihan fisik tunggal yang menghasilkan respon kardiovaskular dan proses metabolisme sementara, yang berlangsung dari beberapa menit sampai beberapa jam. Latihan fisik yang bersifat kronik terjadi ketika latihan fisik tersebut dilakukan berulang kali sehingga menginduksi respon kronis terhadap latihan, dimana mekanisme adaptasi fisiologi dan metabolik menjadi lebih nyata dan bertahan lama.

Latihan fisik yang berpengaruh secara positif untuk mencegah penyakit yang terkait dengan usia, seperti penyakit kardiovaskular, T2DM, dan obesitas. Hal ini terefleksi oleh telomer yang lebih panjang. ${ }^{8}$

Sebuah penelitian pada 2401 volunter diukur panjang telomernya dan ditemukan bahwa telomer lebih panjang sebanyak 240 pasang basa pada individu yang melakukan latihan fisik, daripada yang tidak. Telomer yang diukur ada pada sel leukositnya. ${ }^{6}$

Penelitian Savela S et al. (2013) menyebutkan bahwa aktivitas fisik yang sedang lebih memertahankan panjang telomer daripada aktivitas fisik yang ringan maupun berat pada usia tua. ${ }^{26}$ Juga pada wanita yang sudah menopause, jika melakukan latihan fisik secara teratur. ${ }^{27}$

Mekanisme molekuler yang mendasari bagaimana terjadinya efek proteksi tersebut masih sedikit diketahui. Werner C et al. (2008) menyatakan latihan fisik memiliki efek untuk meningkatkan regulasi protein yang menstabilkan telomer dan menurunkan penuaan selular sampai mencegah apopstosis sel yang dipicu oleh doxorubisin. Doxorubisin adalah obat yang biasa dipakai sebagai agen antineoplastik dan sering memicu toksisitas pada jantung dengan menyebabkan penuaan sel dan apoptosis. Relevansi akan telomer dengan gen proapoptosis ini diuji dengan menggunakan mencit yang dihilangkan bagian TERT dan diberi 2 perlakuan yaitu latihan fisik dan tidak latihan fisik. Pada yang diberi perlakukan latihan fisik mampu meningkatkan aktifitas telomerase dengan meningkatkan aktivitas TRF2 walau diberi doxorubisin, sedangkan efek itu tidak ada pada mencit yang tidak latihan fisik dan diberi doxorubisin. Dikatakan TRF2 ini dapat berikatan dengan TTAGGG, berkontribusi untuk membuat t-loops yang berfungsi untuk memproteksi kromosom. Lalu juga mengenai yang IGF1 juga meningkatkan kerja telomerase sehingga dapat menunda penuaan sel dan kematian sel. ${ }^{28}$

Latihan fisik akan meningkatkan aktivitas telomerase juga ekspresi subunit katalitik dari TERT. Baik Telomerase dan TERT ini terbukti berperan pada pertumbuhan dan survival dari sel otot jantung. Pada tikus transgenik yang di hilangkan Telomerase ribonucleic acid (Terc-/-) mengalami payah jantung yang berat. ${ }^{28}$

Perubahan ekspresi gen tanpa adanya perubahan pada sekuens gen disebut dengan regulasi epigenetik. Ada beberapa mekanisme molekular yang diperoleh dari latihan fisik dan dapat mempertahankan panjang telomer. Sebaliknya kehidupan sedenter, yang kurang latihan fisik dapat mengganggu jalur-jalur 
yang merawat panjang telomer ini. Regulator epigenetik seperti metilasi DNA dan modifikasi histon menjadi suatu hal krusial untuk regulasi epigenetik dari latihan fisik ini. RNA non-coding seperti miRNA menjadi target mRNA shelterin untuk meregulasi protein dan TERRA menghambat pemanjangan telomer dengan berikatan pada cetakan RNA untuk telomerase. Hal ini dilakukan dengan bersaing dengan DNA telomer. ${ }^{8}$

Ada juga regulasi dari ekspresi shelterin dan aktivitas dari telomerase akan meregulasi dari panjang telomer. Sampai pada akhirnya inflamasi dan stress oksidatif memperpendek telomer secara in vivo. Panah kuning yang ada dalam gambar 7 menunjukkan indikasi apakah variabel tersebut meningkat atau menurun, atau bisa jadi keduanya. Hal ini bergantung pada lokasi dan interaksi dengan faktor lain. ${ }^{8}$

\section{Efek latihan fisik terhadap Telomer pada penyakit DM}

Perbedaan DM tipe 1 dan 2 adalah dimana tipe 1 adalah kelainan dimana sel beta pankreasnya tidak menghasilkan insulin sama sekali atau jumlah produksi kurang, sedangkan DM tipe 2 disebabkan oleh adanya resistensi insulin. Resistensi insulin adalah suatu keadaan pada saat sekresi insulin normal atau bahkan meningkat, tetapi target sel insulin kurang sensitif terhadap hormon ini. ${ }^{29}$

Dari beberapa penelitian, terdapat bukti bahwa adanya resistensi insulin ini berkaitan dengan disfungsi mitokondria. Dan ada beberapa hal yang memengaruhi mitokondria ini, seperti faktor genetik, stres oksidatif, penuaan. Dari resistensi insulin akan menyebabkan penggunaan glukosa yang ada di jaringan perifer akan berkurang dan menyebabkan kegagalan fosforilasi kompleks IRS (insulin receptor substrate), penurunan translokasi transporter glukosa (GLUT-4) yang akhirnya menyebabkan kondisi hiperglikemia. Pada awalnya, sel beta pankreas akan melakukan kompensasi dengan mengeluarkan insulin dan menyebabkan hiperinsulinemia. Keadaan resistensi insulin ini akan menyebabkan apoptosis sel beta dan diikuti berkurangnya jumlah sel B di pankreas. Pengurangan jumlah sel beta di pankreas ini akan menyebabkan sintesis insulin juga berkurang dan menyebabkan DM tipe 2. ${ }^{14}$

Menanggapi disfungsi mitokondria yang disebabkan oleh stres oksidatif, maka disebutkan bahwa latihan fisik dapat memengaruhi gen TERT yang mengkode situs katalitik untuk telomerase. Semakin besar aktivitas fisik yang ada mempunyai hubungan berbanding lurus dengan panjang telomer dan aktivitas telomerase. ${ }^{30}$

Keseluruhan mekanisme molekuler, baik aktivitas fisik dan latihan fisik berhubungan dengan telomer yang lebih panjang pada diabetes melitus, belum banyak dimengerti. Kemungkinan yang dapat terjadi salah satunya adalah melalui faktor-faktor epigenetik. Faktor-faktor ini termasuk di dalamnya adalah modifikasi histon (metilasi dan asetilasi). Metilasi DNA bekerja sama dengan asetilasi histon untuk 
membuktikan adanya pemendekan telomer disertai dengan adanya metilasi histon dan perubahan asetilasi pada regio telomer dan subtelomer.

Hipotesis lain adalah terkait dengan efek latihan fisik yang dapat menurunkan kadar gula dalam darah, sehingga menurunkan ROS, dan mencegah pemendekan agresif yang dikarenakan hiperglikemia.

Mengenai dosis latihan yang perlu dan dapat mempertahankan panjang telomer masih memerlukan studi lanjutan. Begitu juga dengan analisa pada panjang telomer, ekspresi protein shelterin, dan aktivitas telomerase dan melibatkan berbagai dosis latihan perlu dilakukan. Terkait dengan meneliti mekanisme molekular, studi-studi ini akan membantu menerangi aspek kesehatan yang terkait dengan telomer untuk mencegah penyakit melalui latihan fisik. ${ }^{8}$

\section{KESIMPULAN}

Pencegahan penyakit metabolik telah banyak dikaitkan dengan latihan fisik, namun mekanisme molecular yang mendasarinya belum banyak diketahui. Penuaan sel yang dapat ditahan oleh aktivitas fisik maupun latihan fisik dapat menjadi salah satu jalur yang dapat dipikirkan mengenai mekanisme molekuler tersebut. Penuaan sel salah satu mekanismenya terkait erat dengan telomer dengan banyak penelitian yang menyebutkan bahwa kematian sel dapat terjadi karena telomer yang telah memendek dan mencapai panjang kritisnya, sehingga pemendekan berikutnya akan merusak DNA genom dan mencetuskan signal bahaya. Signal bahaya ini merupakan salah satu pertahanan tubuh untuk menghilangkan kerusakan yang kemudian menjadikan sel memasuki jalur apoptosis.

T2DM menjadi penyakit metabolik terbanyak dan dapat mengakibatkan berbagai komplikasi yang dapat menurunkan kualitas hidup penderitanya. Telah diketahui dari berbagai penelitian bahwa T2DM menyebabkan stress oksidatif yang berakibat buruk pada panjang telomer dan aktivitas telomerase. Dan diperkirakan melalui mekanisme inilah juga yang menyebabkan timbulnya komplikasi pada T2DM.

Analisis terhadap panjang telomer dikaitkan dengan intervensi aktivitas fisik ini dapat kemudian dicanangkan menjadi salah satu terapi yang baik untuk memengaruhi kesehatan dan juga perlu dipelajari berbagai upaya pencegahan berbagai penyakit melalui latihan fisik. 


\section{DAFTAR PUSTAKA}

1. Shammas MA. Telomers, lifestyle, cancer, and aging. Curr Opin Clin Nutr Metab Care. 2011;141:2834.

2. Goglin SE, Farzaneh-Far R, Epel ES, Lin J, Blackburn EH, Whooley MA. Change in Leukocyte Telomer Length Predicts Mortality in Patients with Stable Coronary Heart Disease from the Heart and Soul Study. PloS One. 2016;11(10):e0160748.

3. Takubo K, Aida J, Izumiyama-Shimomura N, Ishikawa N, Sawabe M, Kurabayashi R, et al. Changes of telomer length with aging. Geriatr Gerontol Int. 2010;10:S197-206.

4. Cui H, Kong Y, Zhang H. Oxidative Stress, Mitochondrial Dysfunction, and Aging. J Signal Transduct. 2012;2012. Tersedia pada: http://www.ncbi.nlm.nih.gov/pmc/articles/PMC3184498/

5. Murillo-Ortiz B, Albarrán-Tamayo F, Arenas-Aranda D, Benítez-Bribiesca L, Malacara-Hernández JM, Martínez-Garza S, et al. Telomer length and type 2 diabetes in males, a premature aging syndrome. Aging Male Off J Int Soc Study Aging Male. 2012;151:54-8.

6. Cherkas LF, Hunkin JL, Kato BS, Richards JB, Gardner JP, Surdulescu GL, et al. The association between physical activity in leisure time and leukocyte telomer length. Arch Intern Med. 2008;168(2):154-8.

7. Park S-Y, Kwak Y-S. Impact of aerobic and anaerobic exercise training on oxidative stress and antioxidant defense in athletes. J Exerc Rehabil. 2016;12(2):113-7.

8. Denham J, O'Brien BJ, Charchar FJ. Telomer Length Maintenance and Cardio-Metabolik Disease Prevention Through Exercise Training. Sports Med. 2016;46(9):1213-37.

9. Botha M, Grace L, Bugarith K, Russell VA, Kidd M, Seedat S, et al. The impact of voluntary exercise on relative telomer length in a rat model of developmental stress. BMC Res Notes. 2012;5:697.

10. Saßenroth D, Meyer A, Salewsky B, Kroh M, Norman K, Steinhagen-Thiessen E, et al. Sports and Exercise at Different Ages and Leukocyte Telomer Length in Later Life - Data from the Berlin Aging Study II (BASE-II). PLoS ONE. 2015;10(12).

11. Testa R, Olivieri F, Sirolla C, Spazzafumo L, Rippo MR, Marra M, et al. Leukocyte telomer length is associated with complications of type 2 diabetes mellitus. Diabet Med J Br Diabet Assoc. 2011;28(11):1388-94.

12. Houben JMJ, Moonen HJJ, van Schooten FJ, Hageman GJ. Telomer length assessment: Biomarker of chronic oxidative stress? Free Radic Biol Med. 2008;44(3):235-46.

13. Wong LSM, Oeseburg H, Boer D, A R, Gilst V, H W, et al. Telomer biology in cardiovascular disease: the TERC-/- mouse as a model for heart failure and ageing. Cardiovasc Res. 2009;81(2):244-52.

14. Wang Z, Deng Z, Dahmane N, Tsai K, Wang P, Williams DR, et al. Telomeric repeat-containing RNA (TERRA) constitutes a nucleoprotein component of extracellular inflammatory exosomes. Proc Natl Acad Sci U S A. 2015;112(46):E6293-6300.

15. Redon S, Reichenbach P, Lingner J. The non-coding RNA TERRA is a natural ligand and direct inhibitor of human telomerase. Nucleic Acids Res. 2010;38(17):5797-806.

16. O'Callaghan NJ, Fenech M. A quantitative PCR method for measuring absolute telomer length. Biol Proced Online. 2011;13:3.

17. Sethi I, Bhat GR, Singh V, Kumar R, Bhanwer AJS, Bamezai RNK, et al. Role of telomers and associated maintenance genes in Type 2 Diabetes Mellitus: A review. Diabetes Res Clin Pract. 2016;122:92-100.

18. Tamura Y, Takubo K, Aida J, Araki A, Ito H. Telomer attrition and diabetes mellitus. Geriatr Gerontol Int. 2016;16:66-74. 
19. Ahmed S, Passos JF, Birket MJ, Beckmann T, Brings S, Peters H, et al. Telomerase does not counteract telomer shortening but protects mitochondrial function under oxidative stress. J Cell Sci. 2008;121(7):1046-53.

20. Townsley DM, Dumitriu B, Young NS. Bone marrow failure and the telomeropathies. Blood. 2014;124(18):2775-83.

21. Salpea KD, Talmud PJ, Cooper JA, Maubaret CG, Stephens JW, Abelak K, et al. Association of telomer length with type 2 diabetes, oxidative stress and UCP2 gene variation. Atherosclerosis. 2010;2091:4250 .

22. Wang F, Reece EA, Yang P. Oxidative stress is responsible for maternal diabetes-impaired transforming growth factor beta signaling in the developing mouse heart. Am J Obstet Gynecol. 2015;212(5):650.e1650.e11.

23. Zhao Z, Reece EA. New Concepts in Diabetic Embryopathy. Clin Lab Med. 2013;33(2):207-33.

24. Warner MJ, Ozanne SE. Mechanisms involved in the developmental programming of adulthood disease. Biochem J. 2010;427(3):333-47.

25. Medicine AC of S. ACSM's Guidelines for Exercise Testing and Prescription. Lippincott Williams \& Wilkins; 2013. 481 hal.

26. Savela S, Saijonmaa O, Strandberg TE, Koistinen P, Strandberg AY, Tilvis RS, et al. Physical activity in midlife and telomer length measured in old age. Exp Gerontol. 2013;481:81-4.

27. Kim J-H, Ko J-H, Lee D, Lim I, Bang H. Habitual physical exercise has beneficial effects on telomer length in postmenopausal women. Menopause N Y N. Oktober 2012;19(10):1109-15.

28. Werner C, Hanhoun M, Widmann T, Kazakov A, Semenov A, Pöss J, et al. Effects of Physical Exercise on Myocardial Telomer-Regulating Proteins, Survival Pathways, and Apoptosis. J Am Coll Cardiol. 2008;52(6):470-82.

29. Lauralee Sherwood. Human Physiology: From Cells to Systems. 9 ed. Boston: Cengage Learning; 2016.

30. Ludlow At, Zimmerman Jb, Witkowski S, Hearn Jw, Hatfield Bd, Roth Sm. Relationship between Physical Activity Level, Telomer Length, and Telomerase Activity. Med Sci Sports Exerc. 2008;40(10):1764-71.

31. Sandin S, Rhodes D. Telomerase structure. Current Opinion in Structural Biology; 2014;25:104-110. 